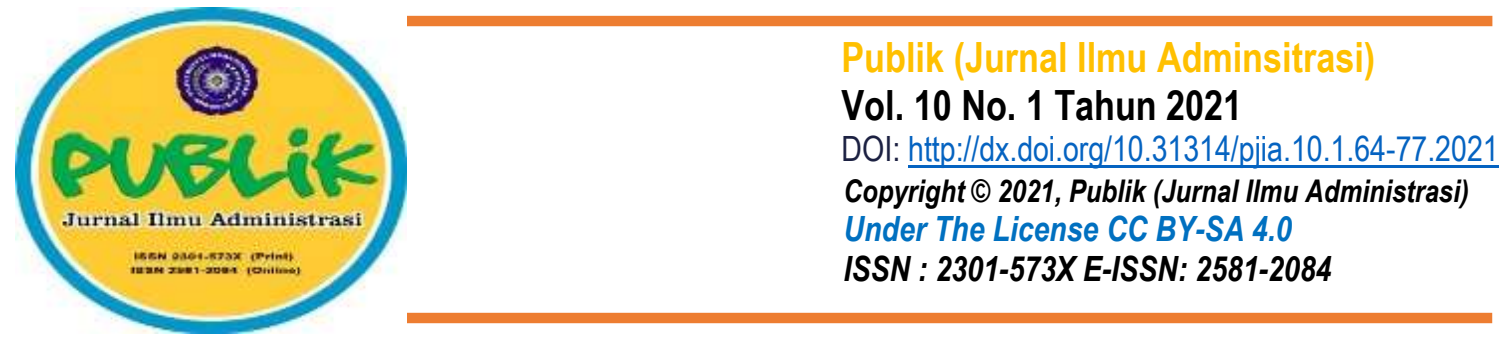

\title{
Governability in Central Sulawesi: An Assessment of Government Capacity to Support Minorities of the Regional Representative of Central Sulawesi Province
}

\section{Asrifai}

Department Science of Government, Faculty of Social \& Political Sciences, Tadulako University, Palu, Indonesia

Email : asrifai@untad.ac.id

Abstract. This article focuses on discussing governance, which is defined as the government's ability in governance. Governability is influenced by the number of parties, the degree of political polarization between parties, party participation in government, and the relationship between most of the parliament and the executive. This research was conducted using a qualitative method with a descriptive analytical approach that describes, describes, and analyzes the governability in Central Sulawesi after the election of governors and vice governors in 2015. Although it has the potential for divided government to occur in the Regional Government of Central Sulawesi because only 13 seats or $29 \%$ of 45 (forty-five) the number of seats in the Regional People's Representative Council (DPRD), but in fact throughout 2016-2020 it was running effectively. There has never been any rejection of government programs by the DPRD during the 2016-2020 government. An interesting finding in this research is that the capacity and background of the regional head from the regional head elections has a big role in building governance with the ability to establish communication and coordination with DPRD members. Regional heads with good capacities and a background in bureaucracy and politicians also influence the performance of local governments and are related to their relationship with the DPRD. The governor who governs and the interaction between the governor and the governed all contribute to governability, including the type of external influence.

Keywords: Governability; Election; Partcipation.

\section{Received:24-04-2021 Revised:26-05-2021 Accepted:30-05-2021}

\section{INTRODUCTION}

Governability is one of the election objectives that must be considered. Governability is related to the government's ability in the quality of the object being governed (Kooiman, 2008; Kooiman et al., 2008; Kooiman \& Mahon, 2008) Elections produce heads of government and DPR members who have important relationships in government administration. A good relationship between the regional head and the DPRD will result in effective governance. Many government relations with the DPR have experienced a bad portrait known as logrolling (Buchanan \& Tullock, 1962) or legislative gridlock (Fiorina, 1992)

The decline in public confidence in democracy is more often caused by the fact that the public does not feel the direct electoral impact on people's lives (Huntington et al., 1975). 
Governability is defined more broadly as the stability of government and its ability to govern. Governability is influenced by the number of parties, the degree of political polarization between parties, party participation in government, and the relationship between the majority of the parliament and the executive, namely the existence of a divided government in the presidential government system, or minority cabinets in the parliamentary government system (Pratama \& Maharddhika, 2016).

The divided government was due to the insufficient support in the legislature. In some regions, there has been a strengthening of the DPRD's functions and even seen that there have been heavy legislatures where the regional head is "powerless" to face the DPRD, especially if the regional head comes from a different party from the majority party in the DPRD. It even seems as if there is a devided government (divided government) as a result of regional heads being held back by the DPRD (Asrifai, 2019).

The lack of support from executive political parties in multiparty parliaments can be referred to as an arithmetic mindset, which is a condition in which parties not supporting the government become dominant in the parliament or none of them become a single majority in the parliament. The involvement of political parties in the DPRD is indeed related to reducing the number of political parties in the parliament and reducing the fragmentation of political parties in the parliament. The small number of political parties and the small fragmentation of political parties clearly facilitates political blocking. Moderate mutiparty systems tend to produce stable coalitions and create effective governance when compared to extreme multiparty systems. The first tends to make decisions quickly because decision making is only determined by two or three parties, while the second is difficult to make decisions because many parties are involved (Pratama \& Maharddhika, 2016).

In terms of deterring politics, the parliamentary system of government is simpler than the presidential system of government. Because in a parliamentary system of government, political parties or coalitions of political parties that control most of the parliament can automatically form a cabinet; whereas in a presidential system, majority parliamentary control does not automatically control the executive because the elected president does not have to come from the party or coalition of parties that controls the parliamentary majority. That is why, in a presidential government system, the schedule for legislative and presidential elections is an important variable to avoid the formation of a divided government (Rabbini in Pratama \& Maharddhika, 2016).

Governability is interesting to study in the Central Sulawesi Government because: first, the coalition of parties supporting the governor and deputy governor in the Central Sulawesi DPRD for the $2016-2021$ period is not a majority coalition, which only consists of 13 seats or $29 \%$ percent of 
the coalition of parties carrying the governor and deputy governor in the Central Sulawesi DPRD for the 2016-2021 period, which is not a majority coalition, which only consists of 13 seats or $29 \%$ percent of the coalition of parties bearing the governor ) the number of parties in the DPRD Central Sulawesi. The coalition of supporters and supporters of the elected governor is the Gerindra Party (6 seats), PAN (3 seats), PKB (3 seats), PBB (1 seat). The minority support can create a divided government (Asrifai, 20019) and the governance of Central Sulawesi is not going well. Second, the competitiveness of the province, Central Sulawesi has experienced a relatively significant decline in macroeconomic stability from 11th in 2015 to 18th in 2017 or has decreased in competitiveness by 7 ranks based on the results of the analysis of the competitiveness of provinces in 2016 by the Asia Competitiveness Institute. Lee Kuan Yew School Public Policy National University Singapore. (Asrifai, 2019) This condition shows the question of how effective the government of Central Sulawesi is.

Governability research in Indonesia, especially after simultaneous elections, is still minimal and even very difficult to find. Governability research in general is more related to the implementation of natural resource system governance (Kooiman et al., 2008), governability is associated with globalization and competitiveness (Ernst \& Haar, 2019), the importance of strengthening governability rather than deepening democracy (Kübler et al., 2020), Disaster management and governability challenges in Indonesia (Efendi et al., 2019). The originality of this research by exploring governability in the relationship of dprd support. Governability with dprd relations is still minimal in giving color in social sciences, especially in Indonesia.

This article contributes to seeing the capacity of regional government after the regional head elections with the support of a minority DPRD. What has not received the attention of local political researchers so far is the support relationship of minority DPRD members in government. The focus of research so far has been the performance of regional governments in the implementation of regional governance without looking comprehensively on the problems of regional governance with the relationship with the DPRD. Bad relations have an impact on government administration. In addition, research so far related to regional elections has looked more at the aspects of implementation, voter behavior, winning strategies (Ibad \& Musdalifah, 2020), citizen political participation (Widhiastini et al., 2019) regardless of post-election administration. 


\section{METHODS}

This study uses a qualitative method with the consideration that this research method can describe problems clearly and in detail (descriptively) regarding the governability of regional government in Central Sulawesi after the election of governors and deputy governors in 2015. This approach seeks to understand how a person experiences and gives meaning to an experience. due to the nature of the problem and the purpose of research which examines the process and reveals the hidden meanings behind real phenomena, and seeks answers to questions that emphasize experiences that are shaped and given meaning by the researcher (Garna, 2001) states that a qualitative approach is characterized by the purpose of research that seeks to understand symptoms in such a way that does not always require quantification, or because these symptoms cannot be measured accurately. As outlined in the previous question; that how the governability of regional government management and power relations after the election for governor and deputy governor in 2015.

The informants of this study were former members of the Regional Government Law Formulation Team, the Chairman of the DPRD, members of the DPRD, the Governor of Central Sulawesi, academics. Data collection techniques used in this study were interviews and documentation studies. Literature study (documentation) is carried out by reviewing and observing reading materials of various theories, books, journals, scientific papers, documents, including regulations and other reference materials deemed relevant to the object of research.

\section{RESULTS AND DISCUSSION}

Governability has been broadly defined in various aspects. The world bank and other international economic actors describe governability as closely related to the notion of transparency (Coppedge, 2001). Initially governability was used to explain the conditions of government and democracy in Europe, America and Japan around the 1970s, at that time there was a decline in public confidence and trust in the functioning of democratic government institutions (Huntington et al., 1975).

Governability is defined as the relationship between the ability to govern the quality of the object of government. It has been argued that "the overall capacity for governance of any societal entity or system" (Kooiman \& Mahon, 2008) (the system-to-be-governed), the subject (the governing system) and the relationship between the two. In a broader context, governability is interpreted as it "could embrace every political phenomenon related to stability, order, and legitimacy: the rule of law, law abidingness, efficient bureaucracy, a strong merit system, low crime 
rates, constitutional succession, low strike rates, long-lasting cabinets, strong corporatist institutions, and many other aspects of institutionalization" (Coppedge, 2001; Huntington et al., 1975) Governability as the ability to govern can embrace every political phenomenon related to stability, order, and legitimacy: rule of law, legal compliance, efficient bureaucracy, strong merit system, low crime rate, constitutional succession, low strike rate, durable, strong cabinet. corporatist institutions, and many other institutional aspects. For this research, governability borrows (Coppedge, 2001) party system on the ability of governments to make policy decisively is the impact of the party system on the government's ability to make firm policies.

The idea that links the ability to rule with the quality of the object of government, with the nature of the subject and the relationship between the two leads us to imagine the government of any system or social entity as a tendency to succeed in its governance. The governor, the governed and the interactions between the governor and the governed all contribute to governing, as do all kinds of external influences. Therefore, governability is defined as: "the overall capacity for governance of any entity or social system" (Kooiman, 2008, 4).

Governability as the overall capacity for governance of any social entity or system (Kooiman, 2008). Governability relates the ability to govern with the quality of government objects with the nature of the subject and the relationship between the two, including the relationship with the DPRD. The relationship of the governor as head of regional government with the DPRD is important in seeing the capacity of local government. In article 1 (paragraph 2) of Law 23/2014 on Regional Government, it is stated that Regional Government is the administration of government affairs by regional governments and regional people's representative councils according to the principle of autonomy and co-administration with the broadest autonomy principle in the system and principles of the Unitary State of the Republic Indonesia as referred to in the 1945 Constitution of the Republic of Indonesia.

As local governments, the DPRD and governors play a role in changes in the regions. The power relationship between the regional head and the DPRD in building governability is very important, as stated by the drafting team for the Regional Government Law: This is very important in regional governance, so when we drafted a law we made a consideration that a regional head must have a representative and there is a minimum limit for nominating candidates so that they "force" a coalition of coalitions of political parties in supporting regional head candidates for regional heads only from other parties whose representatives also from other parties. So that causes at least the regional head to avoid problems, yes, the name mall government means that the regional 
head is not supported by most of the DPRD members in the parliament in the region. (Mallarangeng, 2018)

The idea of connecting the ability to rule with the quality of government objects with the nature of the subject and the relationship between the two brings government or social entities as a tendency for governance success (Kooiman, 2008). The governor who governs and the interaction between the governor and the governed all contribute to governability, including the type of external influence. Order always changes depending on external and internal factors. What may be high governability at some time may be low governability at other times. Likewise, what might be the effectiveness of governance in one place may not be effective in another (Kooiman, 2008).

Post-election local government management sometimes experiences government divide. This is due to party support for regional heads who are not dominant. Divide government also occurs because the implementation of regional head elections and elections for DPRD members do not coincide. As experience in Latin American countries shows, when the election for DPRD members and the election for executive officials is held separately, it tends to result in a divided government (Rabbini in Pratama \& Maharddhika, 2016) On the other hand, when the election for DPRD members and the election for executive officers are held simultaneously, it tends to avoid the formation of a divided government. In other words, the unification of the election schedule for DPRD members and the election for executive officers tends to produce a congruent government, namely a government in which the elected executive officers and the majority of DPRD members come from the same party or coalition of parties.

In the Simultaneous Local Election (Pilkada Serentak) of DPRD members and executive officers, there is a similarity in attitudes between political parties and voters, namely that they prioritize the election for executive officials, then the election for DPRD members. That is what causes the coattail effect, where the electability of executive officials will affect the electability of DPRD members (Rachbini in Pratama \& Maharddhika, 2016), meaning that if a candidate pair wins, then the political party or political party coalition that nominates the candidate pair will win the majority of seats in the DPRD. . In such a political situation, the government will be effective, because all policy plans from the executive officers will easily be approved by the majority of the DPRD, or vice versa.

However, concerns about the occurrence of divided government and the ineffectiveness of the running of the government do not occur in Central Sulawesi. The Central Sulawesi government realizes that the government and the DPRD have the same position and are equal partners: The relationship between the DPRD and the Provincial Government of Sul-Teng is a partnership, having 
the same and equal position, in the sense that they are not mutually supportive, but complementary. Where both of them serve the welfare of the people. Despite their different functions, the DPRD acts as regulator, budgeting, and controlling, and the regional head carries out the role of implementing regional regulations and policies. The executive and the DPRD have the same position as "equal partners" in the administration of government based on the principles of regional autonomy and co-administration. (Djanggola, 2018)

The understanding and commitment of the elected governor affects the situation and relationship between the regional head and the DPRD. Likewise, the ability and influence of leadership affects the relationship between the regional head and the DPRD in the implementation of regional government duties. Since the elected regional head was inaugurated on June 21, 2016, there has never been a program that was not approved by the DPRD, either from the supporting coalition or from non-governor supporting parties. There has never been a program that was not approved by the factions. Never, usually agree with notes. Like the matter of CSR funds, but that too is a misperception. In the past, there was such a thing as CSR, there was a Grant Fund, they thought that CSR was a Grant Fund. After that nothing. In the Law, Regional Government is the administration of government affairs by the regional government and DPRD. So, the government and the DPRD are basically equal and philosophically have equal positions because those who sit as regional heads and DPRD are equally elected by the people through a democratic process

The DPRD supported for the government is running well, government programs have received DPRD support, have never been challenged or rejected by the DPRD. Whereas if we refer to a study conducted by (Mainwaring, 1993), a state that adheres to a presidential system of government faced with a multi-party system will not be able to maintain democracy, due to political uproar in parliament in any form of public policy. In carrying out the DPRD's control function, programs that have not been maximally approved are approved by notes. The DPRD realizes that philosophically the position of the DPRD and the regional government is equal and is equally elected through a democratic process and works in the interests of the people.

To create an effective government, of course, it is influenced by the extent to which the elected regional head can cooperate and establish good communication with the DPRD to support the regional head's program agenda. To maintain relations with DPRD members, I am wise to fund what is called an aspiration fund. Or the fund of thought (pokir) they can propose through musrembang, and please convey it through the relevant OPD. (Djanggola, 2018)

The ability to maintain good relations with the DPRD affects the relationship between the regional head and the DPRD. The governor of Central Sulawesi can maintain an ideal relationship 
between the DPRD and the executive. The governor, to maintain ideal relations with the DPRD, including through the aspiration fund or principal thought (pokir) fund, they can propose through the musrembang, and submit it through the relevant OPD. The government as a whole can be influenced by government actions. Many external factors affect governability. Some of them can be handled well or vice versa (Kooiman, 2008).

Longki Djanggola's commitment and leadership led several parties to serve as candidates for governor and deputy governor for the 2016-2021 period due to the strong popularity and electability of the candidate pairs, which led to parties outside the Gerindra party (Longki Djanggola party) together to carry the pair with the LongkiS tagline. The party that did not nominate candidates for the 2015 Central Sulawesi gubernatorial election was due to: strong public support for the pair of governors and deputy governors for the 2011-2016 period who re-paired. The incumbent pair was promoted by the Gerindra, PAN, PKB and PBB parties. Of the 9 provinces and 152 districts/cities that carry out simultaneous regional elections, only the Central Sulawesi provincial Pilgub has an incumbent pair that progresses again without separating between the governor and the deputy governor, the strength of this support can be seen from the survey institute that always puts the Longki Djanggola and $\mathrm{H}$. Sudarto pairs ahead. in population and electability above $50 \%$. Apart from that, no party cadre was able to compete with the incumbent. Another factor is the difference between the proposed candidates for governor from the regional board of directors and those desired by the central board of political parties such as the Democratic Party and the PDIP Party and another factor is the low electability of candidates proposed by parties who are unable to compete with incumbent candidates.

The implementation of the Central Sulawesi gubernatorial election is interesting because first, the Pilgub Sul-Teng coincided with the implementation of the election for regents and deputy regents, mayors and deputy mayors in 8 (eight) districts / cities). Second, referring to the end of the term of office for the governor of Central Sulawesi which ended on 17 June 2016, the gubernatorial election should be held early 2016. This can be seen from the budget posture in the 2015 APBD where there is no budget for the implementation of the gubernatorial election. However, due to the amendment to Law Number 5 of 2015 which regulates regional heads ending their term of office in the first semester of 2015, the first batch of Pilgub was held simultaneously on December 15,2015, so the budget for the election stages was budgeted in the amended APBD. Third, from 9 (nine) Pilgub in the first batch of simultaneous Pilkada, only the province of Sul-Teng whose term of office ended in 2016 so that the inauguration of the governor and deputy governor was not carried out simultaneously with 8 other governors in February 2016 but waited for the end of the term the 
inauguration was held separately on 17 June 2016. The ability of regional heads to build communication with the DPRD also affects government governability. Regional heads who are only able to communicate well with the bearing parties or the coalition of supporting parties can certainly have an impact on DPRD support and supervision of the programs to be implemented.

Government governance associated with DPRD support can be seen in political fragmentation using the ENPP (effective number of parliamentary parties) Index formulated by (Markku in Laakso \& Taagepera, 1979). The smaller the number generated by the ENPP Index, the smaller the fragmentation of political parties in the parliament, so the more positive influence it will have in creating effective governance. This formula generates four categories of parliamentary systems: first, a one-party system, which means that there is one dominant party; second, a twoparty system, which means that there are two dominant parties; third, moderate multiparty system or simple multiparty, which means that there are three, four, or five dominant parties, and fourth, the extreme multiparty system, which means that there are six or more dominant parties. Up to three elections after the Amendment to the 1945 Constitution, the DPR ENPP Index has never reached the number three, four, or five so that the 2004 Election, 2009 Election, and 2014 Election failed to produce a moderate multiparty system or a simple multiparty system, but only produce an extreme multiparty system (Rachbini; Pratama \& Maharddhika, 2016).

The weak support of political parties in parliament for regional government or the presence of a minority coalition of government supporters, coupled with the presence of more than five political parties that have the relevant capacity to influence decision-making in parliament, is one of the inhibiting factors for regional heads (Pratama \& Maharddhika, 2016). To measure the level of parliamentary fragmentation using the effective number of parliementary parties (ENPP) index model formula (Laakso \& Taagepera, 1979) which aims to determine the number of parties in parliament in decision making and policy formulation. The larger the ENPP index, the more fragmented the parliament and the more difficult decisions to make. To find out the number of relevant parties, (Laakso \& Taagepera, 1979) formulated mathematically the index of the effective number of parliamentary parties or what is known as ENPP. This formula is used to both see and explain how many relevant parties in the parliament were formed after the election. Not only that, this index is also used to see how relevant the political parties in parliament are in making decisions in policy formulation. Douglas Rae (Rae, 1967, pp. 53-58) in (Pratama \& Maharddhika, 2016) formulated the parliamentary political fragmentation index formula that affects the effectiveness of the parliament. This formula is based on the question: is political power concentrated in one party, or is it divided among various political parties? (Rachbini in Pratama \& Maharddhika, 2016) 


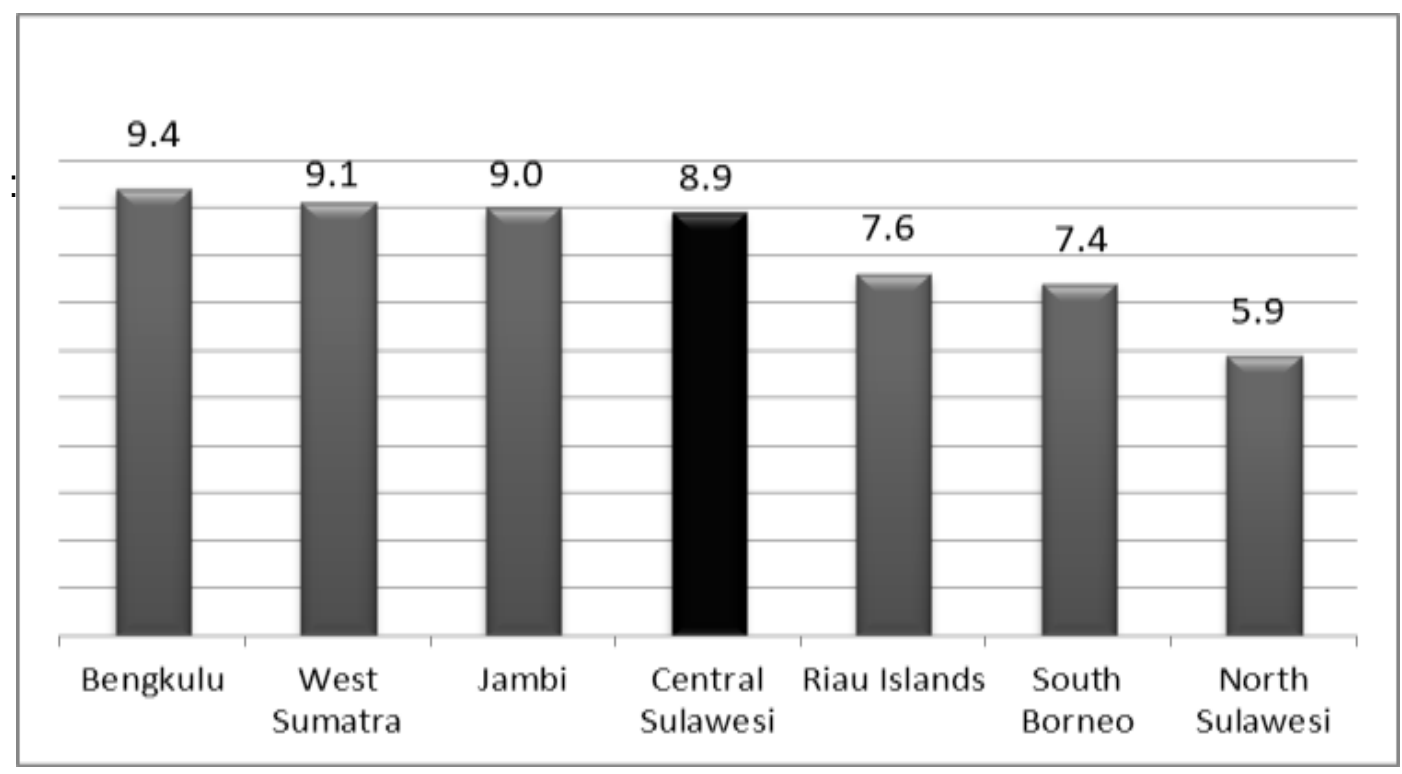

Source: Heroik M Pratama, Mahardika, 2015, Prospek Pemerintahan Hasil Pilkada Serentak 2015

\section{Figure 1 : The index of the effective number of parliamentary parties (ENPP) in 7 Pilkada Provinces in 2015}

From the index in the Figure 1, Central Sulawesi is included in the extreme multiparty system with a value of 8.9 or there are more than 8 (eight) political parties that have the power to influence policy. In this condition, if the elected regional head is unable to build communication or a postelection coalition with a majority of seats in the parliament, in theory it will be difficult to formulate regional regulations including the APBD and may be rejected by the DPRD.

According to several political scientists, including Cheibub et al. (1997), Mark Peyne et al. (2000), Croissant et all (2003) in (Pratama \& Maharddhika, 2016), effective governance or governability is one of the election goals that must be considered, because public disillusionment with democracy is more often caused by problems like this. Governability is the stability of government and its ability to govern. Governability is influenced by the number of parties, the degree of political polarization between parties, party participation in government, and the relationship between most of the parliament and the executive, namely the existence of a divided government or divided government in a presidential system of government, or a minority cabinet in a parliamentary government system.

\section{Dynamics of Governability in Central Sulawesi}

The dynamics of governance related to the government's ability to relate to the DPRD is the condition when the deputy governor of Central Sulawesi was left vacant after the death of the Deputy Governor of Central Sulawesi, Sudarto. The governor's ability to build relations with the DPRD with minority conditions with the support of $29 \%$ of the vote is less than optimal with the difficulty of filling the position of deputy governor of Central Sulawesi. 
Tabel 1: Party Coalition in the 2015 Central Sulawesi Pilgub

\begin{tabular}{lllllc}
\hline \multicolumn{1}{c}{ Candidate } & $\begin{array}{l}\text { Party Politics } \\
\text { (Coallision) }\end{array}$ & Votes (\%) & $\begin{array}{c}\text { Number of } \\
\text { Seat in } \\
\text { Parliament } \\
\text { (DPRD) } \\
(45)\end{array}$ & $\begin{array}{c}\text { Coalission } \\
\text { Seat }\end{array}$ & $\begin{array}{c}\text { Percentage of } \\
\text { the coalition }\end{array}$ \\
\hline Drs. Longki & Gerindra & 742.711 & 4 & 13 & $29 \%$ \\
Djanggola dan H. & PAN & $(54,50 \%)$ & 3 & & \\
Sudarto, S.H., & PKB & $($ Terpilih) & 1 & $24 \%$ \\
M.Hum & PBB & & 1 & 11 & \\
H. Rusdi Mastura & Golkar & 620.001 & 7 & & \\
dan H. Ihwan & Hanura & $(45,50 \%)$ & 4 & & \\
Datu Adam & & & & & \\
\hline
\end{tabular}

Source: adapted from Berita Acara KPU Sulteng 2015.

The relationship between the Governor and the DPRD in implementing programs and policies has received support from the DPRD, but in terms of the replacement of the deputy governor after $\mathrm{H}$. Soedarto died on October 1, 2016, it has dynamics. The election process for the deputy governor of Sul-Teng has been delayed for more than two years, due to differences in political attitudes within the political party (Parpol) that carry the Longki Djanggola-Sudarto pair. Since Sudarto as deputy governor of Central Sulawesi for the 2016-2021 period, a process of submitting a replacement has been carried out in accordance with Law No. 23/2014, the new Deputy Governor of Sul-Teng must be promoted by the political parties that carry the two pairs during the elections, namely the Gerindra Party, PAN, PKB, and PBB. . In accordance with the procedure in the internal mechanism of the coalition, each supporting political party must nominate two candidates for vice governor. Thus, out of the four coalition political parties, they produced eight names. The proposal was then selected again to bring up two candidates to be submitted to the DPRD of Sul-Teng and one of them would be selected as definitive deputy governor. However, there are differences in attitudes within the coalition party body. PAN nominated other candidates, so that three names emerged. The three names were rejected by the DPRD of Sul-Teng, because they were not in accordance with the rules set by the DPRD special committee.

The data of the refugee party in the table above shows that the potential for deadlock in the decision-making that will be taken by the party of the elected governor's party is very high. The condition is reinforced by the absence of agreement built in the internal party of the refugee party regarding the figure to be carried out in place of the deputy governor who died, so that the process of changing the deputy governor has a long process.

The dynamics of the change of deputy governor lasted more than 2 years which made the central government through the ministry of trade reminded the governor and dprd Sul-Teng to solve 
the problem. Finally on 08/07/2019 a plenary meeting was held that determined Rusli Dg Palabbi by defeating Andi Mansur Pasanden. Both were carried out after consolidation between the parties.

On the other hand the dynamics of the replacement of the deputy governor due to the internal turmoil of political parties, the struggle for the East Sulawesi camp (pragmatic geopolitics) and the desire of the non-political party deputy governor (Bahri, 2019) considering the names of candidates carried out at the beginning does not give rise to geopolitical considerations by looking at the origin of the candidate area as a representative of the yanga region in Central Sulawesi.

\section{CONCLUSIONS}

The regional head resulting from the Pilkada has a big role in building effective governance with the ability to establish communication and coordination with DPRD members. Regional heads with a background in bureaucracy and politicians influence the performance of regional governments and are related to their relationship with the DPRD. The administration of Central Sulawesi Province allows for divided government to occur, but in fact throughout 2016-2020 it has run effectively (governability) even though the parties supporting the Central government, not a majority coalition, consist of only 13 seats or $29 \%$ percent of the 45 (four five) parties. in the DPRD Central Sulawesi. The coalition of supporters and supporters of the elected governor is the Gerindra Party (6 seats), PAN (3 seats), PKB (3 seats), PBB (1 seat)

Governability as the ability to rule with the quality of government objects with its subject nature and the relationship between the two brings government or social entities as a tendency to succeed in governance. The governor who governs and the interaction between the governor and the governed all contribute to governability, including the type of external influence. Order always changes depending on external and internal factors. What may be high governability at some time may be low governability at other times. Ultimately, what might be the effectiveness of governance in one place may not be effective in another.

\section{REFERENCES}

Asrifai. (2019). Dinamika dan Pokok-Pokok Perubahan Undang Undang Pemerintahan Daerah. 14 No 02 (Academica Jurnal IImu Sosial dan IImu Politik Fisip Universitas Tadulako), 16171628.

Asrifai. (2019). Transformasi Manajemen Pemerintahan Daerah Pasca Pemilihan Gubernur dan Wakil Gubernur Sulawesi Tengah Tahun 2016-2021.

Bahri, S. (2019). Elit dalam Dinamika Politik Pengisian Jabatan Wakil Gubernur. 14 No 02 
O(Academica Jurnal IImu Sosial Dan IImu Politik Fisip Universitas Tadulako, 14 No 02, 1629 1645.

Buchanan, J. ., \& Tullock, G. (1962). The Calculus of Consent: Logical Foundations of

Constitutional Democrazy. Ann Arbor, Michigan: University of Michigan Press.

Coppedge, M. (2001). Paper prepared for presentation at the conference on "Representation and

Democratic Politics in Latin America," organized by the Department of Humanities of the

Universidad de San Andrés and the Department of Political Science of the University of

Pittsbu. Conference on "Representation and Democratic Politics in Latin America," Organized

by the Department of Humanities of the Universidad de San Andrés and the Department of

Political Science of the University of Pittsburgh.

Djanggola, L. (2018). Governor of Sul-Teng. Interview on 07 June 2018.

Efendi, D., Agustiyara, \& Putra, H. A. (2019). Natural Disasters Management and the Challenge of

Governability in Indonesia. Indian Journal of Public Administration, 65(3), 627-645.

https://doi.org/10.1177/0019556119840953

Ernst, R., \& Haar, J. (2019). Globalization, Competitiveness, and Governability. In Globalization, Competitiveness, and Governability. https://doi.org/10.1007/978-3-030-17516-0

Fiorina, M. . (1992). An Era of Divided Government. Political Science Quarterly.

Garna, K. J. (2001). Metode Penelitian Sosial, Penelitian Dalam IImu Pemerintahan Desain dan Rencana Penelitian. Primoko, Akademika. Bandung.

Huntington, S., Crozier, M., \& Joji, W. (1975). The Crisis of Democracy: Report to the Trilateral

Comission. In American Sociological Review (Vol. 3, Issue 6). https://doi.org/10.2307/2084726

Ibad, S., \& Musdalifah, M. (2020). Partai Politik: Tinjauan Strategi Dalam Meraih Dukungan Massa.

Publik (Jurnal IImu Administrasi), 8(2), 89. https://doi.org/10.31314/pjia.8.2.89-100.2019

Kooiman, J. (2008). Exploring the Concept of Governability. Journal of Comparative Policy Analysis: Research and Practice, 10(2), 171-190.

https://doi.org/10.1080/13876980802028107

Kooiman, J., M, B., R, Chuenpagde, R., R, M., \& R, P. (2008). Interactive Governance and Governability : an Introduction. The Journal of Transdisciplinary Environmental Studies, Vol 7 No 1, 1-11.

Kooiman, J., \& Mahon, R. (2008). Interactive Governance and Governability : An Introduction. 7(1). Kübler, D., Rochat, P. E., Woo, S. Y., \& van der Heiden, N. (2020). Strengthen governability rather than deepen democracy: why local governments introduce participatory governance. 
International Review of Administrative Sciences, 86(3), 409-426. https://doi.org/10.1177/0020852318801508

Laakso, M., \& Taagepera, R. (1979). "Effective" Number of Parties A Measure with Application to West Europe. Comparative Political Studies, 12(1), 3-27. https://doi.org/10.1177/001041407901200101

Mainwaring, S. (1993). Presidentialism, multipartism, and democracy: The Difficult Combination. In Comparative Political Studies (Vol. 26, Issue 2, pp. 198-228). https://doi.org/10.1177/0010414093026002003

Mallarangeng, A. (2018). A Former of Tim Perumus UU Pemerintahan Daerah. Interview, November 2018.

Pratama, H. M., \& Maharddhika. (2016). Prospek Pemerintahan Hasil Pilkada Serentak 2015. Jakarta, Yayasan Perludem.

Widhiastini, N. W., Subawa, N. S., Sedana, N., \& Permatasari, N. P. I. (2019). Analisis FaktorFaktor Yang Mempengaruhi Partisipasi Masyarakat Dalam Pilkada Bali. Publik (Jurnal IImu Administrasi), 8(1), 1. https://doi.org/10.31314/pjia.8.1.1-11.2019 